MINERALOGIA, 40, No. 1-4: 15-30 (2009)

DOI: $10.2478 / v 10002-009-0005-0$

www.Mineralogia.pl

MINERALOGICAL SOCIETY OF POLAND

POLSKIE TOWARZYSTWO MINERALOGICZNE

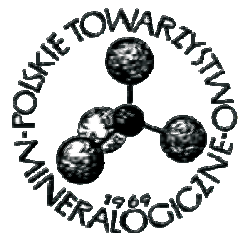

Original paper

\title{
Mineralogy and petrology serving society: challenges for the 21st century*
}

\author{
Dušan HOVORKA ${ }^{1}$ \\ 1 Constantine the Philosopher University, A. Hlinku l, 94974 Nitra, Slovakia
}

Received: October 10, 2009

Received in revised form: March 4, 2010

Accepted: March 15, 2010

Available online: March 30, 2010

Those who are sailing in practice without knowledge are like sailors who embark a ship without ruder and compass and never know with certainty where they are sailing.

(Leonardo da Vinci)

\begin{abstract}
One of the topical problems of science in general at present is spreading the newest discoveries among population as well as among the decision-makers. "Mineralogical sciences" (mineralogy, geochemistry, petrology) affect the wide spectrum of human activities. Such an influence can already be traced in prehistory, and in the modern age the significance of the mentioned geoscience branches is on the increase. The author presents here a review of selected applications of mineralogical sciences in the development of mankind.
\end{abstract}

Key-words: mineralogy in service to society

\section{Introduction}

I regret that not having prepared a lecture on some current, leading problems in mineralogy I will try to summarise some of my views on the role of mineralogy and petrology in the society of the 21 st century. I would consider it normal if some participants of this conference did not

* Invited lecture presented during the VII Meeting of the Mineralogical Society of Poland 
agree with my personal views and the solutions proposed. But you will certainly agree with me that, from time to time, each scientific community should make a summary of the present day status of its own discipline and discuss possible activities and directions for the discipline in the future.

At the very beginning, I would like to note that mineralogy is one of the oldest activities. The use of various minerals and rocks, including plastic clays, has been known since the Palaeolithic and perfected throughout all the following epochs of the human prehistory and early history.

Various minerals and monomineral rocks are part of our everyday life. On wakening in the morning, we observe the sky though window glass made of quartz sand or quartzite - trying to get an impression of the weather that will probably accompany us for the rest of the day. Before leaving home, we usually drink tea or coffee from porcelain cups made of kaolinite and switch off the lighting transmitted to our rooms via copper wires. In this way, we can see that our daily activities closely depend on various raw materials.

The last one or two decades of the last century and the first years of the 21 st have provided evidence that:

- the leading fields of technology, the treatment of diseases (except for those newly appearing), the construction of new instruments, laboratory devices and satellites, rockets, supersonic planes and extremely fast automobiles, have reached their limits. It is clear that future discoveries and the progress of mankind in general will be based on interdisciplinary collaboration of all nations;

- solving the goals of the 21 st century (the shortage of some raw materials, the supply of food and drinking water for millions) must be a provocative aim of both politicians and scientists.

During the last decades of the 20th century, there arose an increasing demand for individuals and institutions dealing with the application of the results of mineralogical research activities to organise activities on a broad international level. Based on worldwide demand, the Commission on Applied Mineralogy (CAM) was established under the aegis of the International Mineralogical Association (IMA).

The scope and goals of the CAM cover a wide spectrum of applied mineralogical activities, e.g. mineral exploration and mining, metallic and non-metallic raw materials, extractive mineralogy, building materials, ceramics, glasses, archaeological materials. The preservation of our cultural heritage, disposal of mine and industrial wastes and medical mineralogy also fall within its activities. It should be underlined that many activities of applied mineralogists are undertaken in close collaboration with scientists of quite different fields of endeavour. Such an interdisciplinary collaboration within the CAM has already led to exceptional results. Some of them will be mentioned below.

In the beginning of this consideration, we have to take into account that rapid progress is being made in the linking of the European states. Increasingly, major problems will be solved on the international level. For instance, one of such concerns is the development of new vaccines for pandemics; recently, the H1N1 virus ("swine flu") has been spreading in both economically developed and undeveloped countries on all continents.

At present, mineralogy concentrates mainly on the following:

- the study of known minerals, the discovery of new species, and new and non-traditional applications of known minerals and rocks; 
- the study of industrial wastes of various kinds that are produced today and those that have already been accumulated;

- technological processes that minimise the output of hazardous elements into the environment;

- finding substitutes for already exploited materials, e.g. artificially made gemstones namely for industrial use, kaolin to be replaced by pulverized limestone in the paper-making industry.

Having been honoured to be a member of the Slovak delegation to the last five General Conferences of UNESCO in Paris, I will now try to present an overview of the general trend of the UNESCO activities, and in doing so, also of mineralogy.

\section{Examples of the application of mineralogy in society}

In the following, I will focus on a few of the activities undertaken by mineralogists in modern society. As it would be impossible to cover all the geoscientific specializations that serve society, I have chosen a few examples.

\subsection{Petrurgy}

Petrurgy represents one of the progressive uses of some basic eruptives and metamorphites. Alkali basalts, amphibolites and some other similar rock types are the main raw material for petrurgy - the production of molten rocks and rock wool as insulation materials. Controlling the chemical stability during the technological process and consequent casting, and the rate of cooling and crystallisation of the melt is a specialised work for mineralogists/petrologists. It is not an academic problem, but a practical one, as I will try to demonstrate with the following examples.

Some 25 years ago, the author was contacted by a technologist from the Nová Ban̆a factory "Technical Glass" in central Slovakia. The factory produced molten basalt in the form of bricks that did not display stable technical parameters. The owners of the factory decided to change their source quarry for another one, some $80 \mathrm{~km}$ more distant. At that time, as I was researching basaltic rocks, I was familiar with the new quarry.

The unstable parameters of the factory products (molten bricks and basaltic wool) were mainly caused by the presence of continental-crust xenoliths in the alkali basalt raw material. I advised the factory to employ 1-2 workers in the existing quarry to pick out all xenoliths of sedimentary and metamorphic rock after blasting. After several months of transporting basaltic raw material from the distant quarry, my proposal was accepted and workers were employed to clean the raw material used in the factory. Their salaries were much lower than the costs of transporting the basaltic raw material.

An example of the sophisticated use of wastes remaining after extraction of metallic aluminium from bauxite concerns a factory located in Žiar nad Hronom in central Slovakia. Huge artificial hills of reddish-brown loose wastes have been accumulated close to the plant. Several years ago, a colleague from my department with collaborators baked this waste under laboratory conditions and made a super hard material for manifold applications. However, the 
utilisation of these wastes in this way faces a major problem; manufacturing of the super hard material requires a high energy input.

The last example of the value of mineralogical techniques dates from the time when the first Czechoslovak nuclear power plant was under construction more than three decades ago. The builder needed several loads of lizardite-chrysotile serpentinite required as a barrier against alpha emissions. The Ministry for Industry commissioned the necessary serpentinite from deposits in the Ural Mts. Blocks of serpentinite transported for more than $3000 \mathrm{~km}$ had to be crushed before use. Somebody from the construction company asked the Department of Mineralogy and Petrology of the Comenius University to do a laboratory study of the serpentinite and general laboratory tests on the raw material. Surprisingly, the lizardite-chrysotile serpentinite from the Ural Mts proved to be identical to the rock from in the Dobšiná chrysotile asbestos quarry. However, there was a significant economic difference: the serpentinite from Dobšiná was already crushed and the transport was 10 times shorter and much cheaper than that of the rock from the Urals.

\subsection{Petroarchaeology/geoarchaeology/archaeometry}

Petroarchaeology, geoarchaeology and archaeometry address inorganic raw materials used in the Palaeolithic and Neolithic. It was 2.5-3 million years ago when an ancestor of Homo sapiens in the Olduvai Gorge in Tanzania picked up a block of rock and used it to kill an animal for food. However, several thousands years were to pass before he could shape lumps of rock into forms useful for cutting, or use them as weapons.

Based on the material used and on the technologies involved, the Stone Age is divided into the Palaeolithic and Neolithic periods. The Palaeolithic is characterised by a chipping technology; the products represent the "chipping industry". To make tools, Palaeolithic man used fine-grained, mostly silica-rich rocks, e.g. flints, metaquartzites, hydroquartzites, radiolarites, radiolarian meta-shales and volcanic glass. Initially, the raw materials were collected on the surface. Later, at the end of the Palaeolithic, they were extracted from mines up to 10-12 m deep; vertical shafts and horizontal galleries have been documented, for example, in Silesia. Miners used fire to disintegrate the flint.

It is highly surprising that already in the Palaeolithic, raw materials or, more probably, final products were transported over long distances. Allow me to present an example that I studied several years ago.

In the Tokaj region in south-eastern Slovakia (famous for its wines), obsidian is one of the products of the late Tertiary rhyolitic volcanism. Obsidian blocks of various sizes in soft volcaniclastics were worked in-situ. Archaeologists have gathered thousands of semi-products and waste from the workings. But more interesting is the fact that eastern Slovakian obsidian implements have been documented in museums more than one thousand $\mathrm{km}$ distant in western Germany - a case of transcontinental transport. Trace elements, including REE, have been used to confirm the identification of the raw materials of implements in Germany and the source obsidian. Another example of transported, this time from Poland, Palaeolithic raw material are the isotropic, banded, so-called "Krzemionki Opatowskie" implements, known from several sites in the Spiš and Liptov regions in Slovakia.

Over millennia, the raw materials used became more diversified and the understanding of rocks and minerals gradually changed. After the retreat of glaciers from Central Europe 
(Neolithic and Eneolithic), the variety of rock types increased and smoothing, polishing, boring and sawing became the main techniques of working them. Stone platelets with sharp ends, which served as saws, have been found on Neolithic archeaological sites distributed around the Malé Karpaty Mts. These saws are made of greenschists with substantial amounts (10-15 vol.\%) of very hard, green, Al-rich spinel crystals. However, the type locality of these rocks is not known.

Implements made of jadeitite provide a further example of long-distance, transcontinental transport. Jadeitite does not occur in the Eastern Alps, the Carpathians or in the Bohemian massif. A jadeitite described by Polish authors in the past was later reclassified as nephrite, an amphibole-bearing metamorphic rock without pyroxene. The jadeitite implements known from the easternmost Europe were usually identified as coming from eastern Moravia (Czech republic). In the last few years, we have identified several jadeitite axes from western Slovakia. But where does the raw material occur? After a literature review, we have deduced that the natural occurrences of the raw material of the axes are jadeitite bodies and river blocks in the Piedmont region on the borders between NW Italy, Switzerland and France. Microprobe studies of jadeitite from Piedmont and from the Slovak axes support this deduction.

It ought to be mentioned that in the Sammardenchia museum in NE Italy, approximately $50 \%$ of the stone implements are made of jadeitite and other high-pressure rocks. Map examination allows concluding that fashioned jadeitite implements were transported from the Piedmont along the Po river valley to the east and, on reaching the Mediterranean, to the north along the "amber route" to the recently discovered localities in Slovakia. This trade route was probably active for a long time.

Concluding this section, I wish to draw your attention to the fact that the work of Polish petroarchaeologists has reached a level that will challenge the next generation to match or exceed.

\subsection{Raw materials and production technology of ancient pottery}

It is difficult to state precisely when manufacturing of pottery began. The first objects made of fired clays were small figurines; one is the well-known Věstonice Venus dated as Gravettian (Upper Palaeolithic) - about 30,000 years BC. It probably took thousands of years for ceramics to become common in prehistoric societies. An established pottery-making tradition existed approximately 12,000 years ago in Japan and China and independently in western Asia some 9000 years ago. It is generally believed that it was from the latter pottery-making region that the ability spread to Europe with the first Neolithic farmers in the second half of the Neolithic. The invention of pottery/ceramics was one of the most innovative developments in technology.

Manufacturing of pottery vessels had a remarkable effect on human life. Pottery products facilitated the transfer of food and, as a consequence, improved the nutrition of individuals. Pottery was a step to the discovery of other important technologies such as metalworking.

The gradual development of pottery annealing and, later, firing can be deduced from the firing temperatures determined from the mineralogy of potsherds. We know that the temperature of an open-air firing place is reflected by minerals that originate at temperatures up to about $650^{\circ} \mathrm{C}$. More sophisticated firing in pottery-furnaces produces associations of higher temperature minerals, including sillimanite, kyanite, mullite, pyroxene, etc. 
Many of the secrets of pottery manufacturing in the Neolithic have been revealed by comparative and experimental, commonly interdisciplinary studies. Application of the modern laboratory techniques would undoubtedly allow discovering of new details concerning pottery-making in prehistory. Pottery, the "guiding fossils" of archaeology for a long time, is the most important basis for archaeological research for a number of reasons, specified below.

- From the Middle Neolithic onwards, vessels fired at the appropriate temperature and for the proper time have become practically indestructible. The new minerals that formed during the firing open new horizons in the study of our prehistory not only for archaeologists but also for mineralogists and petrologists.

- Before the introduction of radiocarbon dating, many relative chronologies were based only on pottery types. Afterwards, in many cases, a single pottery fragment has been sufficient to date at least a phase of human occupation of a site.

- The detailed study of decoration, its style, types of colours and the type of raw material used may be a key to distinguishing local or regional variants. The use of microscopic and other mineralogical methods, together with the spatial distribution of identical pottery styles and identical raw materials, may establish the vectors of the exchange and trade of final pottery goods.

Geological information added to the known archaeological data on prehistoric pottery can be of value in:

- dating archaeological artefacts using standard geochronological methods,

- establishing ancient pottery-making technologies,

- studying the provenance of artefacts and their raw materials,

- reconstructing studies.

Mineralogists can determine clay types, colours used and temperatures of annealing and firing. The spatial orientation of minerals in old pottery can reveal, e.g. whether a potter's wheel was used in paste shaping.

\subsection{The role of mineralogy in gemology}

Gemstones have been highly valued since prehistory for their beauty (colour, transparency), rarity, durability and portability. Gem minerals cut and polished as ornamental stones, in particular, diamond, ruby, emerald, sapphire, opal, turquoise, some varieties of beryl, chrysoberyl, etc., may carry very high prices.

Gemstones may be elements (diamond), aluminosilicates (some 1/5 of the total), oxides (1/7), phosphates, boroslilicates, glasses, titanosilicates, aluminates, etc. In recent years, attempts have been made to use obsidians from eastern Slovakia as decorative materials, and also green epidotites, some types of "wood opal", blue lazulite from the Tribeč Mts and other materials.

During the last decades, industrial gem production has been increasing. Diamond is the most important industrial hard mineral used as an abrasive. Sapphire, ruby, garnet, spinel and many others were formerly used in manufacturing of bearings, in chronometers and watches, etc. In recent years, these stones have gradually been replaced by cheaper synthetics. Industrial abrasive powders and pastes are made of corundum, garnet, topaz mixed with oil and are bound in ceramic substances or metals and shaped into grinding discs. 
Studying of the principal physical parameters of gemstones, i.e. clarity, homogeneity and many other physical properties is a job of mineralogists. The role of the mineralogist, in this context, may be summarised as follows:

- Specialised mineralogists can distinguish, using laboratory equipment, natural and industrial gemstones and artificial gem imitations.

- Gemologists serve as legal experts on the quality of gems or their imitations.

- Mineralogists can aid in the search for new discoveries of precious stone.

In Slovakia, at the Constantine the Philosopher University in Nitra, there has been a B.Sc. course in gemology for several years. Some graduates have continued their M.Sc. studies at the Faculty of Natural Science in Bratislava. One of them has successfully followed further and graduated with a Ph.D. degree.

\subsection{Application of mineralogy in the fields of history, art and conservation}

The technique of obtaining the beautiful and stable blue colour used by the early Egyptians was, for a long time, unknown. For more than thousand years, alchemists and chemists tried to solve the secret. It was only at the end of the 20th century that archaeologists, with a substantial help of mineralogists, chemists and other specialists, succeeded in doing so. The synthetic blue colour of the early Egyptians was prepared using a mixture of six mostly inorganic substances that gave a highly resistant colour, stable over centuries and in various climates. As the red pigment, the Egyptians used natural iron ochres. For the white colour, they used bones fired at a temperature of $400^{\circ} \mathrm{C}$ and added limestone before the mixture was repeatedly fired at $1000^{\circ} \mathrm{C}$. For the green pigment, a mixture of elemental $\mathrm{Cu}$ and $\mathrm{Fe}$ oxides with an addition of quartz and limestone was most often used. The green pigment was also prepared of malachite.

Another well-known example is the famous indestructible blue colour used by the Mayas in Central America to decorate artefacts and sculptures. Later, this colour was used also by the Aztecs. Historians and archaeologists were again faced with questions concerning the techniques of its preparation. The properties of this blue colour are extraordinary; it has a characteristic luminescence that resists all organic solutions, boiling acids, etc. A pigment of this colour was described only in the 20th century. Several decades later, applied X-ray diffraction helped to find that the basic matter in the blue pigment was "sacalum" - a palygorskite-rich clay from Mexico. Later, the use of infrared techniques proved the presence of indigo and leaves of the annila plant (used in the preparation of indigo) in the pigment. But it was only in the year 2000 that the full mystery of the blue colour of the Mayas was definitively solved. An Italian scientist Chiari established the blue colour to be a mixture of palygorskite and indigo. The properties of the pigment reflect the existence of channel-like spaces in palygorskite into which indigo molecules enter to form a stable structural combination of the two.

The application of mineralogical sciences can also be exemplified by colours in the Sixstine Chapel in Rome. When restoration activities began in 1981, one of the first steps was to consult mineralogists on the composition of the red colours used by Michelangelo. Initial results already shown that he had used inorganic as well as organic substances in colour preparation. Thin sections, X-ray diffraction and spectral analyses were used to determine the substances used. Among the many colour-supplying mineral substances identified were graphite, cerusite, chabasite, muscovite, quartz, calcite, cinnabar, realgar, puzuolla (from the vicinity of Naples), 
orpiment, bindheimite, goethite, maghemite, hematite, malachite, glauconite and lazurite. It should be noted that Michelangelo preferred inorganic to organic substances. This identification of minerals used in the Middle Ages represents the first irreplaceable step in restoration and reconstruction work.

\subsection{Stones also die!}

Though we live in the age of atomic energy and aluminium, stones still play indispensable roles in our daily life. In many countries there is an increasing shortage of rocks with required properties, thus recycling (mostly by crushing) of used rocks and concrete has increased in recent years. Such a procedure is even a legal requirement is some countries, where the law stipulates an amount of recycled rocks that must be used in a new project. The real problem, however, is the cost of the energy needed for the recycling. One solution might be storing used stone for a future use, e.g. polished decorative stones used in such outdoor applications as statues, memorials, walls.

Among the most important uses of stone is preparing various types of concrete. But climatic agents, along with other natural and man-produced acids (acid rain) act to destroy concrete-made roads, water channels, airfield runways, monumental buildings, bridges, etc. The problem of concrete deterioration has intensified during the last several decades and will be more serious in the future. Geoscientists can partly eliminate or slow down the process by careful examination of the raw materials used for Portland cement production and of the gravels and sands used for concrete production. In the latter, pyrite and organic substances are especially deleterious.

The Templo Mayor in Mexico City provides an example of the incorrect application of Portland cement in reconstruction. This building was constructed mainly of porous volcaniclastic rocks. The Portland cement used as a binder released, after some time, components that led to the crystallization of gypsum and thenardite $\left(\mathrm{Na}_{2} \mathrm{SO}_{4}\right)$. After hydrating, these minerals alter into mirabilite $\mathrm{Na}_{2}\left(\mathrm{SO}_{4}\right) \cdot 10 \mathrm{H}_{2} \mathrm{O}$ and, in the process, increase their volume several times. Long and thin crystals of mirabilite expand and destroy the porous building rocks.

All involved in the reconstruction of historical building should remember that "stones also die". In our climate, the salt commonly used in winter on roads and pavements destroys concrete, and also the rocks in the lower parts of buildings. In Central European cities, porous limestone (travertine) was used, mainly in the past, as a decorative material. Water present in pores in this rock freezes in the winter and mechanically destroys it. Chemical processes, which follow, are accentuated-especially in the climate with considerable changes of temperature and humidity.

Acid rain, humidity changes, chemical and mechanical processes are factors slowly destroying concrete surfaces, stone statues, and polished decorative rocks used in staircases, bridges and other constructions. It is an important rule that no chemical agents should be used for their cleaning but only water or, in some special cases, carefully chosen organic substances. The Charles Bridge in Prague and the cathedral in Košice are examples of improper renovation practices in the past.

Approximately one third of all historical constructions in the world involve the use of unfired bricks known as "adobe" (from classical Egyptian: "al dub" meaning "brick"). Such material softens on contact with water or air humidity. Conservation of such historical buildings is a serious problem. Applying extremely insoluble calcium oxalate to surfaces of various types 
such as concrete, natural stone, glass, porcelain statues and bridges, etc., is very effective but requires experience and training.

From these few examples significant contributions of mineralogical sciences to the care of our cultural heritage are visible. But for these contributions to be effective, relevant specialists in applied geosciences must be trained, preferably to the Ph.D. level. Some universities offer such training to specialists in the conservation and reconstruction of all kinds of cultural heritage.

\subsection{Exploitation of secondary raw materials (wastes)}

During the last 50 years, mankind have consumed more natural raw materials than they did during all their previous evolution. Technologies using such enormous amounts of materials inevitably produce huge amounts of wastes rich in a great variety of elements and compounds. As the examples below testify, modern technologies can potentially re-use these valuable materials.

Mining wastes arise from mining and utilization of resulting raw materials which should lead to economic prosperity everywhere and the development of mankind generally. However, the wastes also represent a long-term danger to the health. The economic development of post-communistic countries within the EU will entail solving the waste problem - an environmental concern that includes the wastes from previous mining activities. To eliminate the dangers of old wastes, there is a necessity to use the scientific results of mineralogists and other geoscientists.

In considering mining wastes, one cannot ignore the water running from opened underground deposits of metallic and non-metallic ores. Such waters are usually rich in arsenic and other toxic elements, which are, thus, distributed over wide areas. Geoscientists must define the danger; technologists must provide ways to neutralize it. For the countries rich in various kinds of metallic ores, the neutralization of relics of past mining activities is necessary. In such activities, mineralogists and the mineralogical sciences are, and will be, in the forefront.

Slags usually have a semi-crystalline structure: they are composed partly of crystalline phases, partly of glass. Some of these phases, e.g. olivine, oxides of iron, melilite are also common in basic rocks. The determination of slag constituents enables its use as a cement admixture and concrete aggregate, in manufacturing molten rocks, etc. The results of microscopic studies of high-temperature slags reflect the sites of slag formation and that of collection, whereas the degree and character of the crystallization of mineral phases reveals the cooling rate; rapid cooling results in a granular slag. High-temperature slags are typically characterised by their composition as basic or acidic. Slags of both categories are added to cement. The increasing use of slags is controlled by serious determination of their mineral and chemical composition.

Storing and eliminating of radioactive wastes is a current problem. As the number of nuclear power stations increases every year, geoscientists are faced with the problem of finding appropriate storage for radioactive waste. These wastes might be deposited in suitable geological structures in seismically inactive areas without percolating underground water. Alternatively, they might be encased in artificially made materials, e.g. borosilicate glass, developed in recent years with similar or even higher technical parameters likely to be stable in corrosive environments for a long time. 
The materials used for the enclosure of radioactive wastes are glass, ceramics, and some other materials. The corrosion of borosilicate glass is inhibited by increasing the amount of silica in such glasses. Borosilicate glasses are more resistant than ceramic materials at low temperatures, whereas ceramics are more resistant at elevated temperatures in deep-seated depositories. The accumulation of radioactive waste in concrete blocks deposited on the ocean floor may pose a permanent danger and should be excluded.

\subsection{Mineral nanomaterials and their applications}

In the last 2-3 decades, the typical aim in non-metallic raw material research has been the application of silicate nanomaterials in various fields. These nanomaterials involve zeolites, alginites and bentonites, which occur in soils and sediments, mining wastes as well as in wastes originating from metal processing. Research on geological nanomaterials should focus on:

- studying mineral stability of bentonites as potential barriers against radioactive and highly toxic wastes,

- modelling the activity of highly toxic materials and the technical properties of bentonites under extreme conditions,

- studying the origin and function of mineral phases as indicators of the mechanical and chemical stability of some natural processes,

- utilizing Fe oxides and hydroxides as sorbents to remove toxic metals from soils and waters,

- studying metal bonds in alginites as limiting factors in their environmental use.

\subsection{Medical mineralogy - a new challenge for the mineralogist}

Every day, by eating, drinking and breathing, various minerals and elements in the environment move into our bodies. For most of us, the interaction with natural inorganic materials is either harmless or even beneficial when they supply essential nutrients. However, for some people, this interaction with minerals and trace elements can have devastating, even fatal effects. These interactions are the essence of medical mineralogy, a fast growing field that not only involves geoscientists, but also, among others, public health, veterinary, agricultural, environmental and biological scientists. Medical mineralogy, or preferably, medical geoscience, is the study of the effects of geological materials and geological processes on human, animal, and plant health.

The discipline may be new, but the impact of geological materials and processes on human health has been recognized since thousands of years. Mercury, cadmium and selenium were determined in preserved human hair from Kodiak, Alaska. Inhaled soot particles were detected in preserved lung tissue belonging to the Tyrolian ice-man (Ötzi - the man from the Ötztaler Alps on the frontier between Austria and Italy), who died at least 5000 years ago and whose body was kept in good condition due to the enclosing ice tomb.

Some 2400 years ago, Hippocrates and other Hellenic authors had already recognized that environmental factors affected the geographical distribution of human diseases. In 300 BC, Aristotle noted lead poisoning among miners. About then, scientists began to investigate systematically the links between geological substances and medical conditions. More recently, 
collaborating geoscientists and biomedical and public health researchers worldwide have dealt with a wide range of medical geology issues - acknowledging, as it were, that rocks and minerals have long been used to treat maladies such as plague, smallpox and fever.

The term "geomedicine" appeared in the early 1940s in Germany. Since the beginning, the term has meant the impact of the inorganic environment on humans and animals. The term should now encompass medical geochemistry, mineralogy, petrology, etc. The biological impact of the environment on the human body was underlined in the scope of the UNESCO international project "Man and the biosphere" at the beginning of the 1970s. Among the geosciences, only geochemistry and mineralogy sensu stricto help to solve current medical problems. It has been established, for example, that the presence of granite masses represent a permanent danger because of their radon emanations.

Dust particles in the air have long been linked to human health problems. One example is associated with asbestous needles that cause asbestosis. Some 30 years ago, a study of asbestous dust in the USA identified solid fungi spores, a discovery that brought new insight into the role of dust in human diseases on a local and global scale. Another example is the landslide in 1994 in the Simi Valley in California which triggered among valley residents an outbreak of coccidiodomycosis (Coccidioides immitis) or valley fever. We should not forget that our bodies reflect what we eat. The human skeleton has generally two functions. It is a structural support for the muscles and each of its more than 200 bones is a storehouse that reflects our diet. In this way, bones reflect the environment in which they form. The main constituent of bones and teeth is hydroxylapatite. Modern times have brought osteoporosis to many older people and to people eating inappropriate food (low in calcium and phosphorus). Another example pertains to south-western China. Farmers dried corn and chilli pepper indoors during wet autumns. Because the forests had been cut down, they used coal to dry the harvest, but it was the coal with up to $3500 \mathrm{ppm}$ arsenic and the chilli peppers adsorbed a significant amount of arsenic. The peppers enriched in arsenic are a key component of the local diet. As a result, more than 10 million farmers in the area suffer from fluorosis (osteosclerosis knock-knee $=$ medical terminus technicus). This is an exceptional example among more common diseases linked to inorganic substances.

Silicosis, also known as grinders disease, is a form of occupational lung disease caused by inhalation of fine-crystalline silica dust. The disease is marked by inflammation and scarring in the form of nodular lesions in the upper-lobes of the lungs. The acute form is characterized by shortness of breath, fever and cyanosis (bluish skin). Silicosis was first recognized in 1705 by B. Ramazzini who noticed sand-like substances in the lungs of stone cutters. Cutting, blasting, breaking, crushing, drilling and grinding of quartz-rich rocks can lead to silicosis as fine dust particles $(<1 \mu \mathrm{m})$ are deposited in the lungs. The period between initial exposure to silica and the development of X-ray detectable nodular silicosis is usually 10 years. Shorter induction periods, as short as 6 months to two years, are associated with heavy exposures.

World-wide, silicosis is the most common occupational disease, particularly in developing countries. In 1930, pneumatic drilling in a tunnel in West Virginia led to the death of at least 400 workers from the disease. The life expectancy of silver miners in Potosi (Bolivia) is about 40 years. However, the use of protective respirators has brought a steady decline in the death rates. 
Asbestosis is usually detectable after 10 years from the first exposure. The most common symptoms are shortness of breath and a persistent cough. Confirmed laboratory results show that chrysotile due to its chemical composition and structure is strongly acid soluble in lung fluids and, as a result, the individual needles are washed out. Another problem is incurable asbestosis caused by inhalation of amphibole asbestos which are insoluble. Detection is normally made using the X-ray method.

Generally, the presence of tremolite, actinolite, grunnerite, riebeckite, anthophylite, cristobalite, sillimanite, etc. in the air represents a health danger.

Calcification. Bones and teeth constitute the most important solid material in a human body. Both are composed of apatite. But humans often suffer from undesired mineralisation such as kidney stones and gallstones. Another type of mineralisation is the calcification of broken bones, arteries and heart tissue. This process is caused by the growth of a variety of minerals, i.e. calcite, aragonite, apatite, weddellite (calcium oxalate) and others. The laser Raman microprobe technique enables the rapid, non-destructive identification of minerals present in the human body. Raman spectroscopy can be applied to thin sections of human tissue.

Human organisms create minerals within our bodies normally and pathologically. Bones and teeth are examples of normal mineralisation. These are composite materials formed by nanocrystals of the minerals such as hydroxylapatite $-\mathrm{Ca}_{5}\left(\mathrm{PO}_{4}\right)_{3} \mathrm{OH}$. The calcium ureate and calcium oxalate crystals associated with kidney stones and gout are examples of pathological mineralization.

\subsection{Minerals in pharmaceutical industry}

Mineralogy is not typically perceived as being relevant to the pharmaceutical industry. However, more than 30 minerals, both natural and synthetic, are used for various purposes in the industry. They may play roles of active or inert ingredients, colouring agents and filters. The pharmaceutical industry requires permanent controlling of the composition and homogeneity of the minerals used. Standard laboratory mineralogical methods and devices are used for this purpose. This is a research field for mineralogists.

Clay minerals are especially important in the pharmaceutical industry. They have been used for several centuries as active substances (gastrointestinal protectors, laxatives, antiuretics) and as excipients (inert bases, emulsifiers, lubricants) in treatments. Clay minerals are also used in dermopharmacy, in dermocosmetic treatments, in tooth pastes, etc.

\subsection{Forensic science - another application of mineralogy}

Mineralogy is an increasingly important sub-discipline in forensic science. Although various minerals, soil, dust and small rock fragments have been used as forensic trace evidence for many years, their true potential has only begun to be recognized very recently. This reflects the development of modern laboratory equipment and non-destructive analytical techniques which enable the analysis of very small particles of natural or artificial origin. The results can be used in investigations as physical evidence materials of criminal actions.

The police and the other investigative bodies are keen to encourage this development, particularly as many criminals show an increasing awareness of the potential evidence from 
fingerprints, blood and other body fluids. The police techniques range from macro-scale field investigation to micro-scale laboratory evaluation of the physical, chemical and textural properties of individual particles. Many of the techniques used have a wider use in geosciences, archaeology, pedology, etc.

\section{Popularization of mineralogy (results of geosciences)}

In this modern age, the current results of scientific research and the problems of society are so complicated that, e.g. members of decision-making boards need to receive accurate information in a condensed and simplified form. This is no more than what good popularizers of science do. Generally, the presentation of science may be realised in several ways.

1. Popularization by individual scientists, which may take the form of written communications, reports from international conferences, or articles on Nobel Prize winners or notable native scientists and their scientific results. They must be written in everyday language, not that of rigorous science.

2. Some public communication may be the result of cooperation between scientist and journalist. In these cases, the scientist is responsible for the accuracy of the facts, the journalist for the readability of the language.

3. Some journalists specialize in science. In these cases, the presentation is typically brilliant, but the scientific correctness may not be on a desirable level.

The process of creating knowledge-based societies, one of the leading programmes of UNESCO for the current years, presents the challenge of popularizing the scientific results of modern mineralogy, and geology as a whole. In some small countries, there is lack of journalists specializing in this problem. A possible solution is that young geoscientists may initiate such an activity. In some cases, it may become their professional life.

Museums are very effective in the field of science popularization. Their permanent and specialized exhibitions and organized lectures for children, adults and teachers spread science among the general public. However, the museum custodians ought to have an active interest in geosciences.

\section{Conclusion}

The 20th and 21st centuries have brought new challenges for all scientific activities. These concern a world rapidly consuming natural raw materials, a world in which an increasing human population is accompanied by a rapid growth in raw-material demands, a world where environmental conditions increasingly grow more challenging. Thus my basic conclusions are as follows.

1. Science, and especially scientists, must not be blind. The science process cannot be divorced entirely from the end-product. Science is the endless frontier. Science, in our case, mineralogy and petrology, should continue to play a substantial role in driving efficiency in the use of natural resources and in finding future alternatives. Considering the rate at which metals are being consumed, non-metallic resources must be, together with energy resources, 
at the forefront of the challenge. The problems and the solutions geoscientists provide will influence the daily lives of all on this planet, now and in the future.

2. All geoscientists should remember and, likewise, those involved in, e.g. tunnel and highway building, concrete and concrete panel making, or generally, those consuming large quantities of raw materials that the laboratory research methods always come before the building research. It is clear that a new research scope for technical disciplines, particularly material engineering, has emerged. The definition of rule-based relationships between secondary and stable-metastable minerals in building materials, in concrete deterioration, etc., will require the specific approach of mineralogists using microscopical methods of mineral identification, RTG, DTA, electron microscopy and microprobe analyses, etc.

3. In the first decade of the 21 st. century, it is evident that international organizations such as UNESCO and the EU Commission will support scientific research projects promising results that will positively influence mankind in its daily activities. The slogan "Science in the service of society" will be apt for the future. The practical aspects of mineralogy and petrology must not stop. The classical fields of mineralogical study, and its methods, must continue as a new emphasis is placed on the study of newly discovered minerals, their structures and their possible utilization by society. National mineralogical inventories will be constantly updated.

Thus, in the future, mineralogy, petrology, and the other geoscientific specializations will be, in part, focussed on the practical problems of mankind. Based on UNO and UNESCO declarations, the main streams of financial support will, in future, be directed at solutions to the practical, daily-life problems of mankind. For our disciplines, e.g. mineralogy and petrology, the future will see a substantial proportion of university doctorate students addressing such themes.

Practically all classical scientific disciplines have reached, in the last 2-3 decades, limits in their objects of study as well as limits in laboratory equipment. The solution would appear to be interdisciplinary or trans-sectorial collaboration, as an example of such may be the project IGCP/UNESCO Nr. 442 "Raw materials of Neolithic/Aeneolithic stone artefacts and their migration paths in Europe" guided by the author.

Under free market conditions, the population responds to supply and demand. Thus, a sophisticated offer is often a part of the successful selling of a product. Our richness is our knowledge which, when applied, can solve many practical problems of society. In this regard, the popularization of what the geoscientists know and the ability to spread solutions is our irreplaceable richness. The popularization of new scientific discoveries together with an appreciation of the potential applications of various technologies in the use of raw materials needs to be directed at decision-makers and members of parliaments on one hand, and to the general population on the other. It is people with a wide knowledge who will solve society's future problems. For that reason, I encourage our doctorate students to concentrate their attention on these problems. They are pressing. At the end of the day, it is up to us. 


\section{Recommended additional reading}

Baxter P.J. (1990). Medical effects of volcanic eruptions. Bulletin of Volcanology, 52, 532-544.

Hume L.A., \& Rimstidt J.F. (1992). The biodurability of chrysotile asbestos. American Mineralogist, 77, 1125-1128.

Pasteris J.D., Wopenka B., Freeman J.J., Young V.L., \& Brandon H. (1999). Medical mineralogy as a new challenge to the geologist: Silicates in human mammary tissue. American Mineralogist, 84, 997-1008.

Peae K., \& Ceift D.J. (Eds.) (2004). Forensic geoscience: Principles, techniques and Application. London: Geological Society of London.

Schmidt J., \& Štelcl J. (1971). Jadeites from Moravian Neolithic period. Acta Univiversitatis Carolinae. Geologica, $1-2,145-152$.

Szymański A. (1997). Mineralogia techniczna. Warszawa: Wydawnictwa Naukowe PWN. 